Seção Livre 


\title{
Literatura indígena entre tradição ancestral e crítica do presente: sobre a voz-práxis indígena em termos estético-literários
}

\author{
Leno Francisco Danner* \\ Julie Dorrico** \\ Fernando Danner***
}

\begin{abstract}
Resumo
Argumentaremos que a literatura de minorias de um modo geral e a literatura indígena em particular possibilitam a publicização da voz-práxis dessas mesmas minorias (em nosso caso, aqui, dos indígenas) desde uma perspectiva que intersecciona eu e comunidade-grupo e que se funda e se constitui por meio da tríade memória (enquanto comunidade e como vítima), autoafirmação (como minoria) e resistência político-cultural (contra a marginalização, a exclusão e a violência sofridas e vividas como minorias). No que se refere à literatura indígena brasileira, argumentaremos que ela se desenvolve nessa correlação de retomada e afirmação da tradição comunitária ancestral (o que liga de modo totalmente imbricado sujeito estético-literário e comunidade de cultura) e crítica do presente (a constituição de uma voz-práxis vinculada, carnal e política, relatada autobiográfica e mnemonicamente), possibilitandose e impulsionando-se a publicização da própria condição e o ativismo estético-político do indígena frente às instituições e aos demais sujeitos epistemológico-políticos, rompendo-se
\end{abstract}

\footnotetext{
* Doutor em Filosofia pelo Programa de Pós-Graduação em Filosofia da Pontifícia Universidade Católica do Rio Grande do Sul (PUCRS). Professor de teoria política no Departamento de Filosofia e no Programa de Pós-Graduação em Filosofia da Universidade Federal de Rondônia. Orcid: http://orcid.org/0000-0002-2332-3182.

** Doutoranda em teoria da literatura pelo Programa de Pós-Graduação em Letras da Pontifícia Universidade Católica do Rio Grande do Sul (PUCRS). Orcid: http://orcid.org/0000-0002-5428-2432.

*** Doutor em Filosofia pelo Programa de Pós-Graduação em Filosofia da Pontifícia Universidade Católica do Rio Grande do Sul (PUCRS). Professor de ética e filosofia política no Departamento de Filosofia e no Programa de Pós-Graduação em Filosofia da Universidade Federal de Rondônia (UNIR). Orcid: http://orcid.org/0000-0002-4541-1204.
} 
com o silenciamento em torno à questão indígena estabelecido em termos de esfera pública. Assim, nosso argumento central consiste em que a literatura de minorias e a literatura indígena se constituem diretamente como ativismo estético-literário por meio seja da utilização da - e em termos da própria vinculação à - tradição comunitária (o eu-nós lírico, político, cultural), seja da voz-práxis de denúncia e de desvelamento da condição de exclusão, de marginalização e de violência vividas - essa é, defendemos, uma condição fundamental para se analisar o sentido da autoria e da expressão estético-literária das minorias em geral e das produções indígenas em particular.

Palavras-Chave: Literatura de Minorias. Literatura Indígena. Tradição Comunitária Ancestral. Crítica do Presente. VozPráxis.

\title{
Indian literature between ancient communitarian tradition and critic of the present: on the Indian voice-praxis in aesthetical-literary terms
}

\begin{abstract}
We argue that the literature of minorities in general and the Indian literature in particular allow the publicization of the voice-praxis exactly of these minorities (in our case here, of the Indians themselves) from a perspective that intersects I and community-group and founds and constitutes itself by the triad memory (as community and victim), self-affirmation (as minority) and political-cultural resistance (against marginalization, exclusion and violence suffered and lived as minorities). Regarding Indian Brazilian literature, we will argue that it is developed in this correlation of recovery and affirmation of communitarian ancient tradition (which links
\end{abstract}


in a totally imbricated way the aesthetic-literary subject and community of culture) and critic of the present (the constitution of a linked, carnal and political voice-praxis, reported selfbiographically and mnemonically), enabling and promoting the publicization of the proper condition and the aestheticpolitical activism of the Indian regarding institutions and the others epistemological-political subjects, breaking up with the silencing in relation to Indian question established in terms of public sphere. Then, our central argument is that literature of minorities and, then, Indian literature are constituted directly as aesthetic-political activism by means of both the use of and the linking to communitarian tradition (the lyrical, political and cultural I-We), and of the voice-praxis of denounce and unveiling of the condition of exclusion, marginalization and violence which are lived - this is a fundamental condition for the analysis of the sense of the authorship and aestheticalliterary expression of the minorities in general and of the Indian productions in particular.

Keywords: Literature of Minorities. Indian Literature. Communitarian Ancient Tradition. Critic of the Present. Voice-Práxis.

Recebido em: 09/04/2019

Aceito em: 08/06/2020 
"A voz dos oprimidos ecoa igualmente, em qualquer parte do mundo. E temos de ouvi-la para que a justiça se faça a qualquer momento da história" (Eliane Potiguara, 2004, p. 47).

\section{Considerações iniciais}

Neste texto, argumentaremos que a literatura de minorias de um modo geral e, em nosso caso, a literatura indígena em particular constituem-se como uma voz-práxis concomitantemente estética e política, marcada e dinamizada por um eu-nós lírico-político ativista e militante que, desde uma perspectiva memorial, testemunhal e autobiográfica, e sempre na correlação de primeira pessoa do singular e de terceira pessoa do plural (como sujeito marginalizado e como grupo excluído e violentado, indissociavelmente), explicita sua condição de minoria e sua situação de violência, de exclusão e de marginalização para, a partir daqui, desde essa atitude, realizar uma práxis de reconstrução da memória, de anamnese e de catarse da própria dor, da própria exclusão sofrida e vivida, de forma a autoafirmar-se, resistir e lutar desde essa situação de minoria contra a descaracterização, a negação e a destruição que sofrem, que vivem. Com isso, a voz-práxis estético-literária adquire, nas minorias e para elas, um sentido direta e pungentemente político, como crítica social e resistência e luta políticas, em que a rememoração e a elaboração da condição de minoria é, ao mesmo tempo, um impulso auto-reconstrutivo e emancipatório de autoconsciência e de posicionamento público, da explicitação de quem se é e de como se vive, tudo isso sem representações e mediações institucionalistas e cientificistas. Na literatura de 
minorias, portanto, as vítimas falam desde sua condição e esse falar-agir autobiograficamente tem essa dupla base e leva a essa dupla consequência de reflexividade sobre si mesmas (por meio da reconstrução de suas bases antropológicas, socioculturais e epistemológico-políticas) e de resistência cultural e de ativismo político (sob a forma de seu posicionamento público em termos de eu-nós lírico-político, diretamente e sem mediações, em que se denuncia a exclusão, a marginalização e a violência vividas e sofridas). Aqui, por meio da voz-práxis estético-literária, o eu-nós lírico-político adquire carnalidade e vinculação, isto é, a própria vítima, ligada a uma comunidade político-cultural, dela dependente e afirmadora, fala e age em primeira pessoa, sem mediações cientificistas e representações institucionalistas, condição fundamental da crítica social e da emancipação política.

Ora, defenderemos que este é o caso das produções estético-literárias indígenas que estão aparecendo de modo cada vez mais consistente em nossa esfera público-política de um modo geral e no cenário acadêmico, intelectual e artístico brasileiro hodierno em particular. Nelas e por meio delas, o sujeito indígena, constituindo sua voz-práxis na correlação intrínseca e indissociável de comunidade-tradição (sujeito mítico) e individualidade-grupo reflexivo (sujeito histórico), pode concomitantemente reconstruir suas bases antropológicoontológicas e socioculturais, (seu ser indígena, por assim dizer) e, a partir disso, explicitar, sem necessidade de utilizar-se de valores, paradigmas e práticas extemporâneas (bastando, nesse caso, a apropriação e a utilização de sua tradição comunitária e xamânica), a sua própria constituição (e importância) como minoria, bem como denunciar a condição e as experiências de marginalização, de violência e de exclusão que sofreu e sofre. 
Aqui, se intersecciona de modo totalmente interdependente (a) tradição comunitária ancestral e sua memória, por meio de sua rememoração, (b) autoafirmação a partir da reconstrução de si em termos antropológicos, culturais e de tradição xamânica e (c) resistência cultural e luta política, em que a marginalização, a violência e a exclusão sofridas-vividas são publicizadas na esfera público-política e às maiorias, desvelando e denunciando sujeitos sociais e institucionais, estruturas de poder, práticas político-institucionais e valores epistemológico-normativos que, sob a capa do desenvolvimento, da democracia, da razão e até da ciência, em verdade os periferizam e os negam em sua situação. Nesse caso, a literatura indígena, situada dentro desse grande núcleo epistemológico, político e normativo representado pela literatura de minorias, uma vez que é produzida por essas mesmas minorias em termos de correlação de sujeito e comunidade, de eu-nós lírico-político, constituindo-se e dinamizando-se por meio da tríade memória, autoafirmação e resistência, possibilita uma democracia (inclusive epistêmica) desde as margens, desde as periferias, e pelas próprias vítimas de processos de socialização e de subjetivação patológicos, massificadores e homogeneizantes, de modo que as próprias vítimas, uma vez de posse da palavra e como práxis, podem denunciar e lutar contra sujeitos, práticas, valores e paradigmas totalizantes e unidimensionais. Afinal, aqui, a condição de minoria é dada, no mais das vezes, exatamente pela violência, pela exclusão e pela destruição cometidas em nome de formas de vida essencialistas e naturalizadas ou universalistas que assumem uma atuação totalizante, massificadora e unidimensional, isto é, uma atitude destrutiva das diferenças, uma vez que não as reconhecem, inclusive não reconhecendo a própria pluralidade, a própria diversidade. $\mathrm{Na}$ 
literatura de minorias de um modo geral e na literatura indígena em particular, as diferenças falam e agem por si mesmas em um duplo aspecto que é fundamental seja para sua emancipação, seja para a realização de uma crítica social pungente e políticapolitizante: desde sua vinculação antropológico-cultural a um grupo, a uma comunidade singular ameaçada de destruição; e desde sua condição de vítima, de exclusão, de violência e de marginalização que, enquanto singularidade irredutível, é periferizada, silenciada e negada por tendências civilizacionais e práticas institucionais massificadoras, unidimensionais e totalizantes, explicitando-se, aqui, suas experiências de violência, de exclusão e de marginalização.

No decorrer do texto, utilizaremos três conceitos básicos com o objetivo de compreender a literatura produzida pelos intelectuais e escritores indígenas (e mesmo a literatura de minorias). O primeiro deles é o conceito de voz-práxis estéticoliterária como definindo a produção artística indígena. Por esse conceito queremos enfatizar o fato de que os escritores e intelectuais indígenas consideram a expressão escrita e sua publicização enquanto uma catarse relativamente à sua singularidade étnico-antropológica e à objetivação de suas experiências de marginalização, de exclusão e de violência. Isto é, por meio da escrita e de sua veiculação intersubjetiva, os escritores e intelectuais indígenas afirmam e valorizam sua singularidade, ao mesmo tempo em que imprimem um cunho crítico-reflexivo acerca de sua condição político-normativa como indígenas no contexto de nossa sociedade. É uma voz que se faz práxis por meio da escrita e uma práxis que se processa e se dinamiza por meio da escrita, uma voz-práxis de autoafirmação e de resistência, como estamos querendo defini-la. O segundo 
ponto fundamental para a compreensão da literatura de minorias e, no nosso caso, da literatura indígena é o conceito de eu-nós lírico-político. Por meio dele, queremos significar a profunda correlação e dependência entre o escritor/intelectual e o grupo/ comunidade de que faz parte, no sentido de que as experiências do escritor/intelectual de minorias são, de modo primigênio, as experiências, a condição e o caminho desse mesmo grupo ou dessa mesma comunidade de que ele faz parte. Desse modo, o escritor/intelectual fala em nome do grupo, da comunidade, e suas vivências são as próprias vivências comunitárias. Isso é assim pelo fato de que o sujeito pertencente a uma minoria é reconhecido e/ou negado diretamente por causa de sua pertença, uma vez que sua singularidade, que é a singularidade do grupo, consiste em uma produção político-normativa ligada a processos de socialização amplos, a embates entre grupos socioculturais antagônicos que dão exatamente esse sentido e essa produção político-normativos às minorias - minorias são resultado de violência simbólico-material, sua singularidade é vista como chaga, como estigma, como algo a ser escondido, deslegitimado e até destruído pelas maiorias socioculturais. No mesmo diapasão, a manifestação e o aparecimento público-políticos do escritor de minorias representa a manifestação e o aparecimento do próprio grupo de que ele faz parte, o que significa a politização da condição e da causa desse mesmo grupo. Logo, a obra-práxis produzida pelo escritor de minorias é uma obra também coletiva, no sentido de que depende das e se liga umbilicalmente às experiências de vida, às histórias, às práticas e os valores próprios ao grupo de que faz parte. Por isso mesmo, um terceiro conceito fundamental para o entendimento da literatura indígena (e da literatura de minorias) é o conceito de voz-práxis estético-literária carnal, 
vinculada e política-politizante, isto é, uma produção estéticoliterária de caráter ativista, militante e engajado em que o texto expressa uma condição efetivamente vivida, explicitada sob a forma de um relato autobiográfico, autoral, testemunhal e mnemônico da singularidade e da chaga como estigma, como pária, de modo que ocorre uma fusão entre verdade e ficção que rompe com a tradicional imagem ocidental referentemente à literatura, à arte, que a concebe como não-verdade, como mera imaginação livre e criativa, mas sem compromisso com a objetividade epistemológico-moral, situação que somente seria possível por parte do juízo científico. Na literatura indígena, na literatura de minorias, o relato por parte do eu-nós lírico-político advém de suas experiências de marginalização, de exclusão e de violência, e se transformam diretamente em crítica social, resistência cultural e luta política. É, portanto, um relato que se afirma como verdadeiro e, por isso, como político-politizante, como crítica e reflexividade.

Finalmente, é importante delimitar-se outro ponto importante. Estamos falando de literatura indígena brasileira hodierna, querendo, com isso, significar o movimento literário indígena que começa a ser criado e desenvolvido a partir da década de 1990 por autores indígenas como Daniel Munduruku, Kaká Werá Jecupé, Olívio Jekupé, Ailton Krenak, Álvaro Tukano etc. Nesse caso, se trata de uma perspectiva estético-literária produzida por escritores e intelectuais indígenas em torno à sua condição e à sua causa. Não é nem literatura indianista (por exemplo, o romantismo brasileiro) e nem literatura indigenista (por exemplo, a produção antropológica realizada ao longo do século XX por acadêmicos sobre os indígenas), mas criação autoral de indígenas tanto para suas comunidades quanto para 
a sociedade brasileira de modo mais geral. Utilizaremos essa definição genérica de literatura indígena brasileira - produção estético-literária de escritores e intelectuais indígenas - e essa data fundacional - a década de 1990 - como marcos teóricometodológicos no texto, embora sem explicar, dada as intenções dele, de modo mais contextualizado a questão, que fica para outro artigo. No mesmo sentido, utilizamos no texto escritores indígenas como Daniel Munduruku, Ailton Krenak, Kaká Werá Jecupé, Olívio Jecupé, Davi Kopenawa e Eliane Potiguara enquanto representantes e protagonistas desse movimento literário - mas também político, cultural, pedagógico, epistêmico - indígena, mas é importante mencionar-se, de passagem, que hoje esse movimento, que cresce dia a dia, já conta com pelo menos cinquenta e nove escritores e em torno de cento e cinquenta obras publicadas, além de ter se ramificado para áreas como música, pintura, artes plásticas, escultura etc. ${ }^{1}$

\section{Literatura de minorias em termos de eu-nós lírico-polí- tico: o relato autoral da própria experiência de violência, marginalização e exclusão como politização}

Nós consideramos as manifestações e as produções estético-literárias das minorias como um dos fenômenos epistemológico-políticos mais marcantes e fundamentais da constituição de nossa academia e, antes disso, como condição disso, em verdade, da nossa esfera pública, política e cultural democrática na atualidade. Esse fenômeno estético-literário

\footnotetext{
1 Os autores e suas respectivas obras podem ser consultados na Bibliografia das Publicações Indígenas do Brasil, disponível no seguinte endereço: https://pt.wikibooks.org/wiki/Bibliografia_das_publica\%C3\%A7\%C3\%B5es_ind $\%$ C3\%ADgenas_do_ Brasil/Lista_de_autores_(por_origem)
} 
representa exatamente o aparecimento e o ativismo, no âmbito da esfera pública e, portanto, como sujeitos políticos em primeira instância, dessas mesmas minorias político-culturais que, tradicionalmente, teriam sido relegadas às margens da democracia, da academia e do cânone, recebendo, no máximo, um tipo de visibilização indireta em que seriam representadas por um sujeito epistemológico-político extemporâneo que assumiria seu discurso-práxis sem, contudo, dar-lhes efetiva voz e vez, definindo-as e julgando-as, representando-as, mas sem lhes possibilitar participação e expressão (cf.: DALCASTAGNÈ, 2012; RANCIÈRE, 2014; GRAÚNA, 2013; RANCIÉRE, 2009, MIGNOLO, 2007). Elas seriam, aqui, vistas e percebidas a partir de uma estrutura paradigmática formal, imparcial e neutra, em que a descrição objetiva e a orientação axiológica acerca delas dependeriam diretamente do olhar e da interpretação do observador que, de fora e sem qualquer politicidade, carnalidade e vinculação com elas que não a tentativa curiosa de objetiválas, de representá-las fielmente, falaria e significaria sobre elas sem, contudo, romper a separação entre analista e analisado, ciência e cotidiano, modernização e cultura subalterna. Ora, o ativismo estético-literário das minorias quebra com essa dicotomia muito própria de uma perspectiva institucionalista, cientificista e tecnicista que trabalha exatamente sob a forma de dualismos e de fronteiras bem definidas sobre o que é o objeto analisado (a minoria como objeto da análise) e quem é o analista que realiza esse trabalho interpretativo-descritivo (o pesquisador ou o político extemporâneo, impessoal, neutro e imparcial) (cf.: ARFUCH, 2010; ALMEIDA, 2009; CLIFFORD, 2008; KLINGER, 2006).

Assiméque, por exemplo, os indígenas passama expressar-se estético-literariamente em termos autorais, o que significa, nesse 
caso, que suas produções e manifestações simbólicas e artísticas já não necessitam mais da ou não se reduzem e nem se restringem apenas à mediação do cientista social, do analista governamental e do político institucionalista (cf.: MUNDURUKU, 2004, p. 1516; GRAÚNA, 2004, 17-21; LIBRANDI-ROCHA, 2012, p. 179-202; GOLDEMBERG e CUNHA, 2010, p. 117-148; SÁEZ, 2007,p. 11-32; D’ANGELIS, 1999,p. 18-25). No mesmo sentido, as minorias, por meio da reconstrução de sua constituição e de sua condição, possibilitam seja a autoexpressão desde si mesmas e por si mesmas, seja, em consequência, o desvelamento, a denúncia, a crítica e a luta relativamente às situações de violência, de exclusão e de marginalização que sofrem e vivem. Trata-se, no caso das minorias de um modo geral e dos indígenas em particular, de uma voz-práxis que, constituída e dinamizada em termos estético-literários, (a) manifesta-se como eu-nós lírico-político direto, político, carnal e vinculado, em que o posicionamento subjetivo está umbilicalmente atrelado à comunidade, ao grupo e à tradição de que se faz parte; (b) rompe com o formalismo, com a neutralidade, com a impessoalidade e com o cientificismo de abordagens institucionalistas canônicas, instaurando uma perspectiva inclusiva, participativa e direta; bem como (c) consolida a voz-práxis das próprias diferenças, em sua especificidade antropológico-ontológica, sociocultural e epistemológico-política e em sua condição de minorias excluídas e violentadas, como o lugar da autoafirmação identitária, da crítica social e da resistência política, podendo prescindir, em grande medida, de paradigmas técnicos extemporâneos à sua singular visão de mundo (que já é a própria condição de sua vida e, assim, de sua práxis) e negando a dependência estrita a representações cientificistas e institucionalistas de si e de sua 
comunidade-grupo como forma de vinculação e de ativismo social, político, cultural e institucional (cf.: GRAÚNA, 2004, p. 17; COSTA, 2014, p. 65-82; BONVINI, 2006, p. 05-24; GUEDES, 2009, p. 68-80; FINNEGAN, 2006, p. 64-102).

$\mathrm{O}$ primeiro grande núcleo normativo das manifestações estético-literárias das minorias, desse modo, está em que politizam sua constituição e sua condição como minorias sob a forma de um ativismo sociocultural direto, pungente e político, em que o sentido do texto ou da obra produzida está exatamente nessa politicidade, nessa autoexpressão da violência e da exclusão, nessa utilização de sua pertença comunitária, identitária e grupal (seja ela a tradição ancestral, o gênero, o sexo, a cor-raça-cultura etc.) como o elemento a ser afirmado, publicizado, visibilizado e utilizado como ferramenta de autoafirmação, resistência e luta, como base da significação, da crítica, da criatividade. Nesse sentido, a voz-práxis das minorias manifesta-se de modo primigênio em termos de um (e como um) eu-nós lírico-político para o qual a tríade memória, visibilização e luta define não apenas a constituição da obra e a expressão que, nela, se faz da própria pertença societal-cultural-antropológica, mas também a vinculação sociopolítica e, aqui, a atitude antihomogeneizadora e anti-normalizadora que define e dinamiza qualquer práxis emancipatória calcada nas minorias, assumida pelas minorias, que consiste em sua permanente tentativa de publicização e de desvelamento de sua existência como parte da vida sociocultural, como esfera pública, como corpo público, como grupo público, como condição pública que, enquanto tal, tem de afirmar a diferença, a singularidade e a pluralidade como eixo ontogenético de qualquer sociedade-cultura e, assim, de qualquer base paradigmática aberta, inclusiva e não- 
unidimensional. Aqui, um mote fundamental dinamiza a própria práxis dessas minorias: a violência pode ser minimizada ou até erradicada quando se enfatiza e se reconhece a diversidade e o pluralismo - a violência reside na homogeneização, na massificação e na unidimensionalização. Se aprendemos com a diversidade, se compreendemos a diversidade, deixaremos de odiá-la e violentá-la. De todo modo, sem a pluralidade, não há como acabar com a violência.

É nesse sentido, aliás, que definimos os sujeitos e suas manifestações estético-literárias ligados às minorias enquanto constituindo-se e dinamizando-se como e por meio de uma voz-práxis fundamentalmente política e politizante, perpassada por carnalidade e vinculação, no sentido de que aquele que fala-significa em termos autorais é o próprio eu-nós em sua localização mundana, antropológica, social, e não o analista objetivo, neutro, imparcial e impessoal, expressando-se e à sua condição e à sua dor sem mediações e representações, sob a forma de uma voz-práxis em primeira pessoa, como minoria, como vítima, como autor(a) vinculado(a) e militante-ativista que afirma sua pertença e sua condição, que visibiliza-se. Aliás, é interessante observar-se que a voz-práxis artístico-literária das minorias somente pode dar-se em termos políticos, como ativismo político e militante, isso porque uma autoria e uma obra feminista, negra, indígena e LGBTT - às vezes com uma ou mais dessas pertenças ao mesmo tempo (pense-se em Carolina Maria de Jesus e em Eliane Potiguara) -, já na própria expressão de sua condição e vinculação, têm de confrontar a unidimensionalidade e a totalização envoltas em torno à normalização da "brancura", da heterossexualidade compulsória, do falocentrismo ou até da modernidade como formas paradigmáticas, societais, culturais e 
antropológicas basilares do sujeito da fala, da significação e da ação (FERNANDES, 2017, p. 291-326; FERNANDES, 2013, p. 124-148). Já como diferenças radicais relativamente ao padrão normalizado, destoando desse padrão antropológico, societal e paradigmático normalizado e que, portanto, ao ser normalizado, se torna despolitizado e invisibilizado, naturalizado e essencialista, as minorias são políticas, personalizadas e carnais, o que significa que, se partem em termos autorais de uma relação homoafetiva, do preconceito de raça e de cor, do relato da violência sexual e doméstica, ou de uma perspectiva xamânica e comunitária para expressar-se e denunciar a violência de gênero, o etnocídio ou a destruição da floresta, essas mesmas minorias não têm - nem devem ter - outra alternativa que não a politização radical de sua voz-práxis, de sua produção artístico-literária. É o resultado dessa condição de minoria, isto é, que seu discurso e sua ação, uma vez construídos e expressos desde sua situação, tornemse direta e irremediavelmente políticos, anti-normalizadores, atacando de modo pungente os padrões unidimensionais, massificadores e totalizantes. No mesmo diapasão, é exatamente por causa dessa politicidade, dessa carnalidade e dessa vinculação radicais e diretas da voz-práxis das minorias, que fazem parte, que embasam e que dinamizam sua visibilização e seu ativismo público-político, que não há como se avaliar o texto ou a produção delas apenas como texto e produção submissos e enquadrados por paradigmas e sujeitos institucionalistas, cientificistas e formalistas, senão que esse ativismo e essa militância políticos se constituem de modo fundamental no critério definidor e orientador da avaliação e da construção de uma produção estético-literária das minorias e por elas mesmas. Desse modo, a representação extemporânea, imparcial, formal, 
neutra e impessoal das minorias por sujeitos epistemológicopolíticos institucionalizados é posta em xeque pela própria emergência das minorias em sua autoexpressão direta, politizada e carnal, o que significa que a correlação institucionalismo, racionalização e objetividade que guia a construção do cânone e que lhe orienta no que diz respeito à análise e ao enquadramento do texto pelo texto, e desde critérios epistemológicos apolíticos, despersonalizados e descontextualizados, não é efetiva e nem exclusiva para a abordagem e a compreensão das produções estético-literárias das minorias por elas mesmas. Aqui, como dissemos, é sua politização, seu ativismo e sua militância que adentram para o centro da análise-práxis, exatamente porque a politização é a condição ontogenética primigênia de uma minoria como esfera, sujeito e práxis públicos, visíveis e atuantes em termos público-políticos.

Minoria, portanto, é uma condição e uma construção políticas em um duplo sentido: são resultado de processos de massificação, de unidimensionalização e de totalização que periferizam, excluem ou até mesmo destroem o que cai fora da estrutura paradigmática, geralmente essencialista, naturalizada e a-histórica, que embasa tais processos totalizantes, massificadores e unidimensionais, tornando-os normalizados; e sua reconstrução, autoafirmação e resistência acontecem como reação e enfrentamento dessas situações e desses sujeitos ligados à massificação, à unidimensionalização e à totalização, o que significa, em primeiro lugar, a reconstrução e a autoafirmação das minorias por si mesmas, que é a condição básica para não serem completamente assimiladas e apagadas nesses e por esses processos massificadores, unidimensionais e totalizantes. Como reconhecem Graça Graúna e Regina Dalcastagnè, as diferenças 
são fundamentalmente políticas e politizantes, exatamente porque possuem uma condição que, de modo complementar, é antropológica e política, isto é, se por um lado a pluralidade de sujeitos, culturas, valores e práticas é um dado basilar a cada contexto humano localizado histórico-culturalmente, por outro seu enquadramento e sua exclusão a partir de perspectivas essencialistas, biologicistas e coloniais é o dado político mais fundamental do contato, especialmente da correlação de modernidade e do outro da modernidade, o que significa, portanto, que o processo de construção de minorias é político, porque justificado teoricamente e realizado praticamente ele não é um dado e nem uma situação apolíticos, naturais, biológicos, mas exatamente políticos, e o preconceito, o racismo, o sexismo e o etnocídio são suas consequências mais diretas (cf.: DALCASTAGNÈ, 2012, p. 07-48; GRAÚNA, 2004, p. 17-21). Ora, é nesse contexto que a voz-práxis estético-literária é direta e fundamentalmente política, no sentido de que as minorias, de modo correlato, expressam-se e afirmam-se, resistem e lutam, o que significa que a voz-práxis estético-literária $a b$ origine se constitui, se manifesta e se dinamiza politicamente, como expressão de uma minoria por si mesma, desde sua singularidade antropológica e a partir (e contra, evidentemente) sua condição de grupo sociocultural negado, excluído, marginalizado e silenciado. Aqui, a voz-práxis estético-literária enquanto politização radical traz para o centro da esfera pública e como esfera pública o sujeito excluído, que se faz visível, explicitando sua dor sob a forma de um relato autoral, autobiográfico e mnemônico da violência e da marginalização vividas e sofridas. Sobre isso, diz Regina Dalcastagnè: 
Quando entendemos a literatura como uma forma de representação, espaço onde interesses e perspectivas sociais interagem e se entrechocam, não podemos deixar de indagar quem é, afinal, esse outro, que posição lhe é reservada na sociedade e o que o seu silêncio esconde. Por isso, cada vez mais os estudos literários (e o próprio fazer literário) se preocupam com os problemas ligados ao acesso à voz e à representação dos múltiplos grupos sociais [...] Tudo isso se traduz no crescente debate sobre o espaço, na literatura brasileira e em outras, dos grupos marginalizados - entendidos, em sentido amplo, como todos aqueles que vivenciam uma identidade coletiva, que recebe valoração negativa da cultura dominante -, que sejam definidos por sexo, etnia, cor, orientação sexual, posição nas relações de produção, condição física ou outro critério. (DALCASTAGNÈ, 2012, p. 17; o destaque é da autora).

A consideração relativamente ao sentido da autoria e da obra estético-literária produzida, com isso, ao levar em conta o eu-nós lírico-político que, como minoria marginalizada, excluída e violentada, autoafirma-se, publiciza a sua dor e resiste-luta, realiza-se e deve realizar-se por meio da abertura paradigmática que é, ao mesmo tempo, uma perspectiva política e politizante inclusiva e participativa que concebe a expressão artísticoliterária como espaço e práxis da crítica e da politização que, a partir das diferenças, por meio delas, desconstrói, descoloniza, desnaturaliza, recusando a a-historicidade, a impessoalidade, a neutralidade e a imparcialidade do texto-práxis, da autoria e, assim, de seu processo e de seu resultado, a obra estéticoliterária, porque recusa, em primeiro lugar, a normalização e a massificação-unidimensionalização como a base para a compreensão e a constituição de qualquer sociedade-cultura e de seus sujeitos epistemológico-políticos. Ora, a voz-práxis estético-literária é lugar de crítica social e de resistência política 
exatamente porque foi produzida por quem está fora do cânone e do paradigma epistemológico hegemônicos, por quem está fora, antes de tudo, de padrões socioeconômicos, biológicos e religioso-culturais (estes como definindo aqueles). Nesse sentido, o paradigma e o cânone, uma vez que não se separam do contexto social, político, cultural, religioso e econômico no qual se fundam e do qual emergem, não podem ser percebidos como fim em si mesmos e nem sequer, na maioria dos casos, como caminho e espelho por meio dos quais as diferenças são percebidas, significadas e avaliadas-enquadradas desde e como uma perspectiva institucionalista, cientificista, técnica e apolítica que despersonaliza, descontextualiza e desvincula o sujeito da práxis de sua obra, o sujeito e sua obra como memória, autoafirmação, resistência e luta - o sujeito e sua obra como politização direta, radical, inclusiva e abrangente.

Ora, se o primeiro núcleo normativo das produções estético-literárias das minorias é sua politização radical, o segundo núcleo normativo fundamental delas está, conforme pensamos, em que a manifestação público-política dessas mesmas minorias, sob a forma de sua voz-práxis artísticotextual, consiste na correlação e na imbricação umbilicais em termos de eu-nós lírico-político. Com efeito, a manifestação estético-literária do(a) autor(a) subalterno(a) está ligada ao e dependente do grupo comunitário ou identitário ou social de que faz parte. Não é uma obra individualizada e uma postura apolítica, descontextualizada, despersonalizada e desvinculada desse grupo comunitário ou identitário ou social, senão que é uma voz-práxis de uma minoria, de um sujeito que é parte de uma minoria, sem qualquer possibilidade de separação entre esses dois elementos. Aqui, portanto, temos a implosão de uma 
perspectiva estética, epistemológica e política que chamaríamos de liberal ou burguesa, em que o indivíduo assume uma postura introspectiva e individualista que pode separar-se facilmente de e negar diretamente seu ativismo e sua militância políticos e sua vinculação e seu pertencimento socioculturais, adotando um sentido voyeurista e apolítico que faz da literatura, quando muito, um espaço de fruição e de diletantismo, mas nunca de crítica, de politização e de educação, como se ela não tivesse nada a ver com isso. Ora, essa visão liberalizante do âmbito, do sujeito e da produção estético-literários, altamente apolítica, despolitizadora, individualista e voyeurista, tende exatamente a anular o potencial crítico e emancipatório da arte, tornando-a meramente em produto comercial e espaço apolítico de autoexpressão de um(a) autor(a) cego ao contexto de emergência de si e de sua obra, como alguém grandemente descompromissado relativamente ao cotidiano. $^{2}$ Essa apoliticidade, essa descontextualização e essa despersonalização, de todo modo, são postas em xeque pela vozpráxis estético-literária das minorias, uma vez que, como vimos dizendo, estas são totalmente políticas (dada a sua condição política de minorias, como diferenças) e agem, significam e produzem simbólica, artística e politicamente na correlação de indivíduo e comunidade, de eu-nós lírico-estético-político (como desenvolveremos logo adiante, essa dupla condição - voz-práxis política-politizante e correlação eu-nós lírico-estético-político

- é fundamental para compreender-se a produção artístico-

2 Essa noção de indivíduo liberal, como que cego ao - ou separado do - contexto, sem vinculação e pertença, pode ser percebida diretamente na definição da autoria proposta por Walter Benjamin enquanto especificando o autor moderno. Como dissemos, a autoria própria ao intelectual de minorias destoa diretamente dessa definição de autor moderno, posto que vincula identidade $\mathrm{e}$ pertença, história pessoal e condição coletiva, arte e política. Diz Walter Benjamin, acerca da autoria moderna: "Podemos fazer uma travessia marítima e cruzar o oceano, sem terra à vista, vendo unicamente o céu e o mar. É o que faz o romancista. Ele é o mudo, o solitário. [...] O romancista se separou do povo e do que ele faz. A matriz do romance é o indivíduo em sua solidão, o homem que não pode mais falar exemplarmente sobre suas preocupações, a quem ninguém pode dar conselhos, e que não sabe dar conselhos a ninguém. Escrever um romance significa descrever a existência humana, levando o incomensurável ao paroxismo." (BENJAMIN, 1987, p. 59). 
literária indígena no Brasil contemporâneo). Sobre isso, Daniel Munduruku diz de modo enfático:

A literatura é, para nós, uma forma de atualizar nossos conhecimentos antigos. Por intermédio dela, pretendemos desconstruir a imagem negativa que fizeram de nós e mostrar que somos parte da aventura de ser brasileiros, ainda que tenhamos diferenças em nossa compreensão de humanidade. Atualizar nossos saberes ancestrais usando os equipamentos que a sociedade, dita civilizada, criou é a nossa maneira de mostrar que não somos seres do passado, muito menos do futuro. Essa atualização mostra que estamos na Terra para ficar e queremos ensinar nossa maneira de manter o planeta vivo, queremos gritar para o mundo todo que somos parte e que ainda dá tempo de reverter o quadro vermelho de sangue que foi pintado ao longo de nossa história, ainda dá tempo. (MUNDURUKU, 2016, p. 191-192).

Note-se, aqui, a afirmação de que a voz-práxis estéticoliterária, conforme a concebe Daniel Munduruku, é "nossa" forma de retomar e renovar as tradições, "nossa" forma de autoafirmação, de resistência e de luta, o que enfatiza essa relação fundante entre eu-nós lírico-estético-político como a base para a construção da obra e de sua vinculação epistemológica, política e social. Note-se, ainda, a afirmação de que "não somos seres do passado e nem do futuro", mas exatamente do presente e que, como presente, atualizam-se e reatualizam-se, tornando-se visíveis e atuantes em termos de esfera público-política como condição de sua autoafirmação e, assim, de sua resistência e de sua luta quanto mais se fizerem visibilizados em termos público-políticos, mais podem tornar pungente e politizada a condição indígena brasileira, o que mostra como a produção estético-literária indígena é ativismo e militância políticos em primeira mão, com base naquela intersecção de eu-nós lírico-político. Como 
estamos enfatizando, a perspectiva autoral e a produção estéticoliterária das minorias, se é política e politizante, contextualizada, vinculada e personalizada, também é, como condição necessária e consequente disso e para isso (dessa relação umbilical entre expressão artístico-literária e politização das minorias e por parte delas), diretamente ligada ao grupo de que emerge o(a) artista - por vezes, aliás, um(a) artista coletivo(a). E não haveria como ser diferente: no mesmo momento em que a expressão estético-literária das minorias é política-politizante porque as minorias são construções e produtos políticos, assim como sua autoafirmação e resistência-luta são práxis política em sentido estrito e pungente, a vinculação e a ligação com o grupo de que se faz parte é não apenas o ponto constitutivo e dinamizador da perspectiva autoral e de seu produto estético-literário das minorias por si mesmas, mas também a referência antropológica, epistemológica e política sempre necessária e fundamental para que uma minoria possa assumir publicidade, protagonismo e visibilização. Nesse sentido, se o autor liberal-burguês pode ser apenas voyeurista, um indivíduo apolítico, descontextualizado e descomprometido, o(a) autor(a) literário periférico e subalterno tem de inevitavelmente remeter-se em primeira e em última instância ao grupo minoritário ou subalterno de que faz parte, do qual ele assume a herança cultural, do qual ele bebe as experiências de exclusão, de violência e de marginalização, e ao qual ele, por meio de sua voz-práxis carnal e vinculada, politiza, promove e publiciza.

É isso que torna a voz-práxis estético-literária das minorias altamente política e politizante, carnal, vinculada, contextualizada e personalizada. Ou seja, o sentido político dela, em termos de autoafirmação, resistência e luta como minoria excluída, 
violentada e negada, se dá e se processa exatamente por causa da ligação umbilical, inextricável e indissociável entre o eu que narra e o grupo ao qual ele pertence, constituindo-se, assim, em um eu-nós lírico-estético-político que se tematiza e se dinamiza por meio da explicitação simbólica da própria dor, publicizandose, visibilizando-se e, assim, politizando-se diretamente, ao mesmo tempo em que desvela, desnaturaliza e, assim, politiza os sujeitos, os paradigmas, as práticas e os valores normalizadores, ossificados e a-históricos que constroem e legitimam o sentido negativo e periférico das minorias, que as invisibilizam e, ao fim e ao cabo, as anulam e destroem. Veja-se alguns exemplos, específicos à literatura indígena brasileira hodierna. Em seu livro Xerekó Arandu: a Morte de Ângelo Kretã, Olívio Jekupé se manifesta nessa correlação de autocompreensão individual e pertença coletiva, ao retratar sua experiência citadina:

Em seguida, saí e fui direto para a pensão, onde estavam minhas coisas. Lá as pessoas me olhavam curiosas. Sempre acho engraçado como as pessoas me tratam na cidade, sempre me perguntam se sou boliviano, chileno e até argentino. É triste que o brasileiro não identifique mais pessoas com fisionomia indígena! (JEKUPÉ, 2002, p. 07-07).

Note-se, nessa passagem, o fato de o narrador ser visto e tematizado a partir de uma condição genérica coletiva que, no caso da colonização, foi tematizada de modo caricato: sua expressão indígena é confundida com outra nacionalidade, o que, conforme desabafo desse mesmo narrador, revela desconhecimento de sua condição indígena - ou mesmo nãoreconhecimento dela. Por outro lado, nas próprias palavras dele, apresenta-se essa vinculação com a referida condição como seu elemento de identificação e de sentido, obviamente a partir da 
percepção de que, para Olívio, essa condição indígena não é uma caricatura nem um elemento de deslegitimação de si, mas sua base de compreensão e de atuação. Ora, o mesmo pode ser dito da literatura de Kaká Werá Jecupé, o qual, em sua obra Oré Awé Roiru'a Ma: todas as vezes que dissemos adeus, expressase, do mesmo modo, a partir da intersecção de identidade e pertença, fundando sua perspectiva literária exatamente nela. Aqui, o narrador assume-se como porta voz de seu povo, buscando publicizar a singularidade étnica que lhe constitui e, ao mesmo tempo, denunciar a situação histórica, política e cultural própria à colonização e gerada por esta - nesse aspecto, a visibilização da condição indígena seria o núcleo de crítica social relativamente à nossa sociedade nacional. De sua voz e por meio de suas experiências, por conseguinte, emerge na esfera pública um Brasil contraditório, e não a pátria da democracia racial, um Brasil que ainda assume elementos coloniais (como o racismo e o fundamentalismo) fatais para sua democratização efetiva. Ele diz:

Pois aceitei por inteiro a missão de ser um porta-voz à surda metrópole com seus ornamentos de neon e a beleza cosmética de sua face, cujos antepassados vestiram meu povo de costumes, hábitos, espelhos. E que, embora os hábitos procurassem ter feito monges, criaram violências. Assim, fui compreendendo que há algo da terra, do ar, da água e do fogo do Conhecimento da tribo de onde vim que precisa ser partilhado. Para ensolarar turvas sombras, perigosas, de jaguares, capazes inclusive de fazer com que, por ignorância, destruam a grande mãe. Então, eu vim para mostrar a nudez do meu povo. (JECUPÉ, 2002, p. 16-17).

Por isso, o eu-nós lírico-estético-político ligado às minorias, como minoria, é um sujeito militante e ativista e produz uma obra que é, ela também e em consequência, ativista e militante, política 
e politizante, vinculada, carnal e personalizada: é a obra das minorias por si mesmas, a práxis de autoafirmação, resistência e luta das minorias por si mesmas. Aqui, a leitura e a compreensão tanto da perspectiva autoral quanto do produto crítico, criativo e político é exatamente uma expressão artística de um grupo, a literatura indígena, a literatura feminista, a literatura LGBTT, a literatura negra etc., o que também significa que o(a) escritor(a) é o(a) escritor(a) indígena, feminista, LGBTT, negro(a), sem qualquer possibilidade de dissociação dessa correlação e dessa pertença e sustento mútuos. Sobre isso, perceba-se um poema de Eliane Potiguara, que explicita a dinâmica do eu-nós lírico-político e, assim, sua profunda politização da sociedade envolvente, que advém exatamente da escrita como práxis, da superação da invisibilização, do silenciamento e do privatismo como minoria:

Que faço com minha cara de índia?

E meus cabelos

E minhas rugas

E minha história

E meus segredos

Que faço com minha cara de índia?

E meus espíritos

E minha força

E meu Tupã

E meus círculos?

Que faço com minha cara de índia?

E meu Toré

E meu sagrado

E meus "cabocos"

E minha Terra?

Que faço com minha cara de índia?

E meu sangue

E minha consciência 
E minha luta

E nossos filhos?

Brasil, o que faço com a minha cara de índia?

Não sou violência

Ou estupro

Eu sou história

Eu sou cunhã

Barriga brasileira

Ventre sagrado

Poro brasileiro

Ventre que gerou

O povo brasileiro

Hoje está só...

A barriga da mãe fecunda

E os cânticos que outrora cantavam

Hoje são gritos de guerra

Contra o massacre imundo (Potiguara, 2018, p. 29-30).

De todo modo, como estamos enfatizando e sustentando ao longo do texto, é essa ligação umbilical que coloca a voz-práxis artístico-literária das minorias na vanguarda da autoafirmação, da resistência e da luta dessas mesmas minorias contra os processos de negação, de exclusão e de violência sofridos e vividos, possibilitando sua politização radical, sua visibilização e seu protagonismo público-políticos e, portanto, fazendo da voz-práxis estético-política dessas mesmas minorias, calcada no eu-nós lírico-político, o núcleo da revitalização e da dinamização sociocultural, epistemológico-política e paradigmático-acadêmica na contemporaneidade. Aqui, se a democracia é fortalecida e dinamizada, ela o é pela centralidade das diferenças e, no nosso caso, da voz-práxis estético-política em termos de esfera público-política e como esfera públicopolítica, radicalmente ativista e militante, como práxis antinormalizadora. Essa, de todo modo, é a novidade da literatura 
indígena brasileira hodierna, como desenvolveremos na próxima seção.

\section{Literatura indígena da tradição ancestral à crítica do presente: sobre o sentido e a dinâmica da produção artís- tico-literária indígena brasileira}

Com efeito, conforme acreditamos, um dos pontos nodais, distintivos e constitutivos tanto das produções estético-literárias das minorias quanto, de modo mais específico, das produções estético-literárias indígenas está nessa correlação de politização do(a) autor(a) e da obra, uma vez que se funda no sentido e na condição das minorias, promovendo sua singularidade e denunciando sua marginalização, na intersecção e na dependência umbilicais de indivíduo e comunidade, que gera um eu-nós lírico-estético-político ativista e militante, que visibiliza e publiciza as bases antropológico-ontológicas, socioculturais e epistemológico-políticas de sua comunidade, de seu grupo, utilizando-as como forma de autoafirmação, de resistência cultural e de luta política contra a situação de marginalização, de exclusão e de violência vividas e sofridas. Portanto, aqui, conforme já salientamos acima, a tríade memória, autoafirmação e resistência demarca a voz-práxis estético-literária das minorias por si mesmas como possuindo um sentido e uma dinâmica diretamente políticas e politizantes, vinculadas, carnais e personalizadas (a literatura indígena, negra, feminista e LGBTT, como dissemos). No caso da literatura indígena brasileira produzida na atualidade, conforme argumentaremos a partir de agora, a retomada e a valorização da pertença comunitária, da tradição ancestral e xamânica é o ponto de partida do 
posicionamento autoral e da construção da obra, permitindo, por um lado, autoafirmação e autoexpressão identitárias e, a partir daqui, como consequência disso, resistência cultural e luta política. Ou seja, a literatura indígena (e as produções artísticas indígenas de um modo mais geral) constitui-se, legitima-se e dinamiza-se em um movimento que vai da afirmação da tradição à (e como) crítica do presente, em que a situação de periferização, exclusão e subalternidade é reelaborada exatamente por meio da assunção e da utilização das próprias bases antropológicas e comunitárias e dos próprios instrumentos simbólico-normativos ali fundados como práxis política e politizante para a crítica social - inclusive, como quer Daniel Munduruku, como práxis pedagógica da própria sociedade brasileira de um modo mais geral, como uma tarefa assumida pelos/as indígenas. Ele nos diz, sobre esse sentido político-pedagógico assumido pela literatura indígena:

É que para mim a escrita era uma espécie de instrumento pedagógico. Sempre tive no horizonte o objetivo de auxiliar a sociedade brasileira a conhecer, a compreender e a aceitar a diversidade indígena. Era uma questão de honra. Não me via como um escritor, mas como um educador cuja principal tarefa era 'jogar piolhos' na cabeça da sociedade e deixar ela se inquietar, pensar, se coçar e refletir sobre sua própria identidade étnica. Até hoje penso assim, mas agora já sei que sou um escritor que faz uma literatura militante, comprometida com a transformação social. [...] passei a aceitar que escrever e ser professor faziam parte do mesmo processo de redescoberta da ancestralidade brasileira. (MUNDURUKU, 2016, p. 177-178).

Ailton Krenak atua e se manifesta na mesma dinâmica, referentemente à atuação público-política tanto do Movimento Indígena brasileiro quanto dos intelectuais-escritores indígenas, 
de modo que, com ele, a voz-práxis indígena assume, conforme nosso argumento no texto, esse sentido de aproximação política, cultural, epistêmica e pedagógica com a sociedade brasileira mais ampla, buscando assumir protagonismo em torno à condição e à causa indígenas e, com isso, tentando "pacificar" nossa modernização conservadora. Ailton nos diz:

Nós sentimos que temos uma responsabilidade muito grande com relação aos novos moradores aqui da América. Eles vieram para cá - em alguns casos fugidos, escorraçados das suas regiões de origem, desprezando esta terra, e agiram aqui - na maioria das vezes - como estrangeiros. Nós queremos conversar com os novos brasileiros para ver se eles conseguem entender os sinais dessa terra, amar esse lugar, protegêlo, viver aqui não como quem vive num acampamento (KRENAK, 2015, p. 82).

Com isso, alguns elementos fundamentais presentes na autoria e na produção estético-literária indígenas merecem ser destacados, no que se segue, como princípios epistemológicopolíticos fundamentais para pensarmos não apenas os(as) autores(as) indígenas e suas obras dentro do contexto canônico, paradigmático e acadêmico, mas também o profundo sentido anti-paradigmático, anti-institucionalista e político-politizante que a literatura indígena (e, de um modo mais geral, as literaturas de minorias) viabiliza e dinamiza em termos socioculturais, em termos de esfera público-política. Entre esses princípios, podemos citar: (a) a tríade memória, autoafirmação e resistêncialuta; (b) a imbricação umbilical entre eu-nós lírico-político, o que significa que a afirmação da tradição é a condição para a crítica do presente, correlatamente ao fato de que o/a escritor/a de minorias fala-age em nome do grupo e este aparece diretamente na autocompreensão daquele/a, bem como no resultado em 
termos de obra-práxis; (c) o profundo ativismo e militância políticos, uma vez que a literatura indígena denuncia e visibiliza a situação de exclusão, de marginalização e de violência, ao mesmo tempo em que afirma uma expressão estética e realiza um posicionamento público em que os indígenas se assumem como protagonistas de sua história e como sujeitos criadores; e (d), em tudo isso, a profunda constituição carnal, política, vinculada e personalizada dos(as) escritores(as) indígenas e de suas produções, em que eles se filiam diretamente ao movimento e à causa indígenas, assumindo seus valores e afirmando sua identidade, denunciando a violência vivida e sofrida e propondo um diálogo-práxis junto à modernidade que possa sensibilizála para a questão indígena (cf.: SÁ, 2012; CÉSAR, 2011; CESARINO, 2011; D’ANGELIS, 2007; THIÉL, 2006; SÁEZ, 2006; ALMEIDA E QUEIROZ, 2004; RISÉRIO, 1993). Em síntese, aqui, definimos a literatura indígena como intersecção de afirmação e de utilização da tradição comunitária, ancestral e xamânica e (como) crítica do presente. Isso fica muito claro nas palavras de Daniel Munduruku, em sua obra Memórias de índio: uma quase autobiografia:

A literatura nunca foi meu objetivo único e nem o mais importante. Foi instrumento para alcançar um propósito que ainda trago em meu peito: formar pessoas mais conscientes de seu pertencimento ao mundo em que vivemos. [...] No meio do caminho havia uma pedra ou muitas pedras, quase montanhas inteiras. E elas ainda estão lá para serem removidas. Removidas? Não sei, de verdade. Também no meio do caminho houve pessoas solidárias que se juntaram ao trabalho de retirá-las ou rodeá-las. Gente tocada pela tradição que carrego comigo na palavra e no corpo. Gente que sentiu o drama do descompasso construído pela história de sofrimentos que nossas gentes indígenas passaram e passam. Gente acolhedora que soube apreciar os saberes. 
(MUNDURUKU, 2016, p. 201-202; os destaques são nossos).

Nesse caso, conforme argumentamos, a produção estéticoliterária indígena não possui um sentido intrínseco e um fim em si mesmo, a obra pela obra, isto é, a produção de um texto sem um contexto político e um sujeito contextualizado política, social e culturalmente. Também não é uma obra autoral despersonalizada e desvinculada, sem carnalidade e ligação étnica, sociocultural e política: é a expressão identitária e comunitária de um povo, de um grupo, e realça sua singularidade, seu drama e sua força vital pulsante, transformando-se direta e pungentemente em ativismo e militância políticos na esfera pública, como esfera pública. Aqui, o caráter autoral da literatura indígena, isto é, o fato de que ela é produzida por escritores/ as efetivamente indígenas, leva a que as narrações tenham um cunho experiencial que, na sua publicização, desvela a condição do próprio povo ao qual pertence o/a escritor/a, constituindo um relato autobiográfico, testemunhal e mnemônico que se baseia na tradição comunitária e que se dinamiza nas experiências de exclusão, de marginalização e de violência vividas e sofridas, buscando, a partir disso, o diálogo com a sociedade em que esses sujeitos indígenas estão situados A afirmação de Daniel Munduruku, de que escreve literatura e trabalha como professor, de que escreve concomitantemente à atividade de ensino, tem como cerne o chamar a atenção, visibilizar, publicizar e politizar a causa indígena, para dar a conhecer a todos e todas a condição indígena. Ora, este posicionamento serve como parâmetro e orientação para a compreensão da autoria e do sentido da obra indígenas como práxis político-normativa, como crítica do presente a partir do testemunho e do grito do grupo 
marginalizado, violentado e subalternizado. Em suma, escrevese e produz-se estético-literariamente com objetivos políticos e pedagógicos, como forma de visibilização e de publicização da própria condição, o que também representa uma catarse, uma anamnese e uma afirmação-promoção de si, de seus valores e de seus dramas. Essa é, ainda nas palavras de Daniel Munduruku, a base constitutiva e dinamizadora fundamental de sua produção como escritor indígena, a saber, a afirmação do movimento indígena como crítica do presente:

É verdade que há muito o que fazer. Nossos povos continuam vítimas da ganância ocidental; da busca de lucros pela exploração das riquezas minerais; da expropriação dos saberes ancestrais. Continuam sendo excluídos do processo histórico e acusados de atrapalhar o progresso e o desenvolvimento pelo simples fato de defenderem o lugar onde moram como algo sagrado; por entenderem a terra não como objeto de cobiça, mas como pertencimento; por se recusarem a entrar no jogo do capital que nega as identidades, as diferenças e o direito conquistado. A literatura não resolveu problemas, é verdade. Não ajudou a demarcar terra ou a parar as máquinas de destruição que constroem hidrelétricas e barragens que detonam o meio ambiente; não impediu massacres ou homicídios cometidos por pessoas que se sentem senhoras do mundo. A literatura não tem essa pretensão. Ela alimenta a esperança, a utopia. Ela desentorta pensamentos equivocados; oferece consciência e alimenta o espírito das pessoas. É assim que, ao menos, penso e atuo. Sei que há outras pessoas que pensam assim e que conseguem, através dos devaneios poéticos e literários, transformar outras pessoas e colocar dentro do coração delas motivos para lutar. Nossa literatura é um grito de libertação. E este nasce quando há opressão entalada na garganta. (MUNDURUKU, 2016, p. 203-204).

Primeiramente, a literatura não liberta pura e simplesmente 
da condição de marginalização e de violência porque a emancipação somente se dá por meio da práxis, como práxis de crítica e de luta, que exige autoconsciência, participação, inclusão e politização abrangentes. Mas é exatamente por estar consciente disso que Daniel Munduruku pode afirmar que sua literatura e que a literatura indígena, filiando-se ao movimento indígena, constituem-se em estopim para a conscientização, em mote para a resistência e em instrumento para a reflexividade em prol dos povos indígenas, em nome deles e por eles. Novamente: a produção estético-literária das minorias de um modo geral e, nesse caso, da literatura indígena em particular não são um fim em si mesmo, senão que se ligam diretamente à promoção da causa dessas mesmas minorais, desses mesmos povos indígenas, de modo que sua produção, uma vez tornada visível na esfera pública, assume de modo direto uma constituição e um ativismo políticos e politizantes que são fundamentais para promover e dinamizar a causa das minorias, a causa indígena, à qual está vinculada. Aqui, a produção estético-literária indígena politiza, dramatiza e torna pungentes a causa e a condição indígenas, uma vez que se trata do(da) próprio(a) indígena falando por si mesmo, desde si mesmo, de seus valores, de suas práticas, da exclusão, da violência e da marginalização vividas e sofridas, uma vez que as viveu na pele, na carne, na cultura, na sua própria autocompreensão como indígena. Ora, ao politizar e dramatizar a causa e a condição indígenas, a voz-práxis indígena lança na esfera pública o grito por justiça e por reconhecimento, verdadeiro estopim da transformação. É nesse sentido, retomamos, que Daniel Munduruku concebe sua produção estético-literária enquanto filiada ao movimento indígena. Aliás, nas passagens acima, de Daniel Munduruku, aparecem mais dois 
pontos fundamentais que definem a constituição, a vinculação e a politização da literatura indígena, que são a ênfase na tradição comunitária e ancestral como base da autoexpressão, da autoafirmação, do ativismo e da militância públicos, e a fala em nome da comunidade ou do grupo de origem, o que vincula a produção autoral a esta mesma comunidade ou grupo de que se faz parte. Nesse caso, é importante analisarmos algumas passagens fundamentais de uma das obras indígenas mais magníficas e impactantes produzidas recentemente no Brasil, que é o textopráxis A Queda do Céu: Palavras de Um Xamã Yanomami, escrito em parceria por Davi Kopenawa, xamã yanomami, e Bruce Albert, antropólogo francês estudioso do povo yanomami. Nela, Davi Kopenawa utiliza-se de uma perspectiva autoral marcada pela correlação e pela ligação umbilical entre tradição comunitária e xamânica com relato testemunhal em primeira pessoa, imbricando de modo fundamental o eu-nós líricoestético-político como base constitutiva e mote orientador da produção textual e de sua vinculação político-normativa. No caso de Davi Kopenawa, portanto, a afirmação dessa mesma tradição comunitária e xamânica, como singularidade indígena, é o ponto de partida e o substrato antropológico a partir do qual o indígena significa-se e publiciza-se e, depois, realiza uma crítica à modernização - a voz-práxis indígena como crítica do presente por meio da afirmação e da utilização de sua tradição comunitária e xamânica. Senão vejamos. Primeiramente, um dos grandes núcleos do texto, que lhe fundamenta e lhe dinamiza a constituição interna, consiste na valorização e a utilização da tradição comunitária e ancestral como base de sua autoafirmação, de sua significação e de seu posicionamento público-político: 
[...] os brancos acham que não sabemos nada, apenas porque não temos traços para desenhar nossas palavras em linhas. Outra grande mentira! Nós só ficaríamos ignorantes mesmo se não tivéssemos mais xamãs. Não é porque nossos maiores não tinham escolas que eles não estudavam. Somos outra gente. É com a yãkoana e com os espíritos da floresta que aprendemos. Morremos bebendo o pó da árvore yãkoana hi, para que os xapiri levem nossa imagem para longe. Assim podemos ver terras muito distantes, subir para o peito do céu ou descer para o mundo subterrâneo. Trazemos palavras desconhecidas desses lugares, para que os habitantes de nossa casa possam ouvi-las. Esse é o nosso modo de ficar sabedor, desde sempre. Não é possível desenhar as palavras dos espíritos para ensiná-las, pois são inumeráveis e não têm fim. Não daria em nada querer escrevê-las todas. Quando os brancos estudam, cravam seu olhar em velhos desenhos de palavras. Depois relatam seu conteúdo uns aos outros. Não veem nem ouvem eles mesmos as imagens dos seres do primeiro tempo, por isso não podem conhecê-las de fato. Nós, ao contrário, sem caneta nem peles de papel, viramos fantasmas com a yãkoana para ir muito longe, contemplar a imagem dos seres no tempo do sonho. Então, os xapiri nos ensinam suas palavras e é desse modo que nosso pensamento pode se expandir em todas as direções. Sem nos juntarmos com nossos antigos para beber yãkoana e sem fazermos descer os espíritos da floresta, não poderíamos aprender nada. (KOPENAWA \& ALBERT, 2015, p. 458-459).

Note-se a ideia fundamental aqui: sem a tradição comunitária representada pelo xamanismo não seria possível aos indígenas aprenderem qualquer coisa e, em verdade, como antonomásia, somente por meio dessa tradição ancestral constituída e dinamizada em termos do xamanismo é que os povos indígenas podem aprender, significar e posicionarse frente a si mesmos, frente ao mundo e frente aos brancos. No caso de Davi Kopenawa, podem-se perceber duas atitudes 
fundamentais no que tange à construção e à enunciação de sua voz-práxis: a primeira delas é o recurso permanente à tradição comunitária e xamânica, o que significa tanto utilizá-la como base de suas reflexões e de suas invectivas quanto assumi-la como fundamento de autoafirmação e de crítica, reconhecendo que o ser indígena é indissociável dessa mesma tradição e constituição comunitária e xamânica, em que a ancestralidade representa o ponto nodal de sua singularidade antropológica e de sua condição como minoria marginalizada; a segunda delas consiste em que seu diálogo-práxis frente à modernidademodernização, frente aos brancos, como se pode perceber, se processa e se dinamiza em uma tentativa de apresentar e enfatizar sua singularidade e, com isso, recusar qualquer perspectiva homogeneizadora, massificadora e unidimensional, seja ela cultural, epistemológica, política, econômica e mesmo religiosa - nesse caso, a fundamentação da normatividade social, uma tarefa que é cara à modernidade ocidental e que foi definida por ela como correlação de racionalização científica e subjetivismo axiológico, ocorre exatamente por meio da remissão ao mundo e aos seres do primeiro tempo, acessíveis pelo xamanismo, sem prejuízo da objetividade e da vinculação da crítica, sem prejuízo, inclusive, de uma ação política justificada e pungente. Em suma, é por meio do recurso à tradição comunitária, ancestral e xamânica que se dão a autoafirmação e a autoexpressão indígenas e, como consequência disso, seu posicionamento, seu ativismo e sua militância público-políticos enquanto crítica do presente, crítica da modernização. É nesse sentido, aliás, que Davi Kopenawa conferiu a Bruce Albert as palavras, as práticas e os valores que perpassam a obra A Queda do Céu: Palavras de Um Xamã Yanomami, isto é, com o objetivo de dar a conhecer 
aos brancos a cultura yanomami, de modo a conscientizá-los de sua singularidade, de suas contribuições aos próprios brancos e, por fim, de modo a criticar esses mesmos brancos em sua sanha instrumentalizadora, massificadora e economicista relativamente à natureza e à terra, mas sempre desde sua - do povo yanomami visão de mundo, vista como fundamental para a própria correção das mazelas da modernização:

Como eu, você ficou mais experiente com a idade. Você desenhou e fixou essas palavras em peles de papel, como pedi. Elas partiram, afastaram-se de mim. Agora desejo que elas se dividam e se espalhem bem longe, para serem realmente ouvidas. Eu the ensinei essas coisas para que você as transmita aos seus; aos seus mais anciãos, aos seus pais e sogros, aos seus irmãos e cunhados, às mulheres que você chama de esposas, aos rapazes que irão chamá-lo de sogro. Se lhe perguntarem: "Como você aprendeu essas coisas?", você responderá: "Morei muito tempo nas casas dos Yanomami, comendo sua comida. Foi assim que, aos poucos, sua língua pegou em mim. Então, eles me confiaram suas palavras, porque lhes dói o fato de os brancos serem tão ignorantes a seu respeito".

Os brancos não pensam muito adiante no futuro. Sempre estão preocupados demais com as coisas do momento. É por isso que eu gostaria que eles ouvissem minhas palavras através dos desenhos que você fez delas; para que penetrem em suas mentes. Gostaria que, após tê-las compreendido, dissessem a si mesmos: “Os Yanomami são gente diferente de nós e, no entanto, suas palavras são retas e claras. Agora entendemos o que eles pensam. São palavras verdadeiras! Afloresta deles é bela e silenciosa. Eles ali foram criados e vivem sem preocupação desde o primeiro tempo. O pensamento deles segue caminhos outros que o da 
mercadoria. Eles querem viver como lhes apraz. Seu costume é diferente. Não têm peles de imagens, mas conhecem os espíritos xapiri e seus cantos. Querem defender sua terra porque desejam continuar vivendo nela como antigamente. Assim seja! Se eles não a protegerem, seus filhos não terão lugar para viver felizes. Vão pensar que a seus pais de fato faltava inteligência, já que só terão deixado para eles uma terra nua e queimada, impregnada de fumaças de epidemia e cortada por rios de águas sujas!”.

Gostaria que os brancos parassem de pensar que a nossa floresta é morta e que ela foi posta lá à toa. Quero fazê-los escutar a voz dos xapiri, que ali brincam sem parar, dançando sobre seus espelhos resplandecentes. Quem sabe assim eles queiram defendê-la conosco? Quero também que os filhos e filhas deles entendam nossas palavras e fiquem amigos dos nossos, para que não cresçam na ignorância. Porque, se a floresta for completamente devastada, nunca mais vai nascer outra. Descendo desses habitantes da terra das nascentes dos rios, filhos e genros de Omama. São as palavras dele, e as dos xapiri, surgidas no tempo do sonho, que desejo oferecer aqui aos brancos. Nossos antepassados as possuíam desde o primeiro tempo. Depois, quando chegou a minha vez de me tornar xamã, a imagem de Omama as colocou em meu peito. Desde então, meu pensamento vai de uma para outra, em todas as direções; elas aumentam em mim sem fim. Assim é. Meu único professor foi Omama. São as palavras dele, vindas dos meus maiores, que me tornaram mais inteligente. Minhas palavras não têm outra origem. As dos brancos são bem diferentes. Eles são engenhosos, é verdade, mas carecem muito de sabedoria. (KOPENAWA \& ALBERT, 2015, p. 64-65). 
Note-se, mais uma vez, a centralidade e a importância do eu-nós lírico-estético-político calcado na explicitação, na valorização e no uso da tradição comunitária, ancestral e xamânica como base seja da própria autocompreensão, autoafirmação e autoexpressão, seja, a partir daqui, do diálogopráxis intercultural, da crítica à modernização, da crítica do presente, da afirmação do movimento indígena. Davi Kopenawa, em verdade, constrói sua crítica à modernidade/modernização a partir da reafirmação de sua tradição comunitária e dos valores, das práticas e dos símbolos que a constituem, o que nos permite sustentar, como estamos fazendo ao longo de todo o texto, que, no caso das produções estético-literárias indígenas, a crítica do presente se funda na retomada e na valorização da tradição comunitária, ancestral e xamânica que constitui e que dinamiza a vida cotidiana dos povos indígenas. Sem essa profunda vinculação e dependência ao contexto antropológico-ontológico e sociocultural e dos valores epistemológicos, políticos e estéticos ali fundados, não conseguiríamos entender nem o sentido das produções estético-literárias indígenas, nem sua militância e seu ativismo diretos, pungentes, em que o eu-nós lírico-político fala de si, de suas tradições, valores e práticas, de suas experiências traumáticas de violência, exclusão e negação sofridas; mais ainda, essa tradição comunitária, ancestral e xamânica embasa, motiva e impulsiona o eu-nós lírico-político ao enquadramento da modernização a partir exatamente desses mesmos valores comunitários e xamânicos, valores, práticas e simbologias que apontam para a crítica do presente como a condição para a afirmação e a resistência do grupo subalternizado e silenciado como sua alternativa e sua perspectiva fundamentais. Por isso mesmo, a voz-práxis de Davi Kopenawa, assim como a de Daniel 
Munduruku, a de Ailton Krenak, a de Kaká Werá Jecupé, a de Olívio Jekupé e a de Eliane Potiguara, citadas nesse texto como autores(as) representativos do movimento indígena brasileiro hodierno, entre tantos outros, dinamiza-se de modo direto por meio do xamanismo, isto é, por meio do fato de, contra qualquer instrumentalização e descaracterização de si, dos outros e da própria natureza, enfatizar exatamente o sentido espiritual, normativo e político da vida, bem como sua interdependência e intersecção umbilicais ${ }^{3}$. Daí porque, conforme pudemos ler na passagem acima, Davi Kopenawa escreve sua obra aos brancos no sentido de alertar para o fato de que a natureza não é pura instrumentalidade acessada pela técnica, como se fosse uma res extensa pura e simplesmente; ela é viva, como qualquer ser humano e, mais do que tudo, ela é a condição para que o ser humano possa continuar existindo nesse planeta. Ora, essa constituição ontológica da natureza, desvelada e reproduzida via xamanismo, correlacionada ao direito de os povos indígenas viverem em sua singularidade, é que se coloca como o núcleo do posicionamento público do xamã yanomami e de sua postura de crítica do presente via retomada da tradição comunitária indígena. Nesse sentido, Davi Kopenawa pode não apenas prescindir do uso de paradigmas, de práticas e de valores extemporâneos para significar e dinamizar sua causa, mas também afirmar enfaticamente que essa mesma tradição comunitária, ancestral e xamânica é suficiente tanto para a autocompreensão e a vida cotidiana dos indígenas por si mesmos quanto em termos de sua postura de crítica à modernização, de crítica do presente. Ele diz:

Apesar de tudo isso, os brancos já nos ameaçaram

\footnotetext{
3 Diz Ailton Krenak, sobre isso: "Nós temos uma consciência cósmica da existência dos povos nativos do mundo e é por isso talvez que a gente não divide o mundo em departamentos, mas nós entendemos o mundo como lugar” (KRENAK, 2015, p. $153)$.
} 
muitas vezes para nos obrigar a abandonar os xapiri. Nessas ocasiões, só sabiam dizer: "Seus espíritos estão mentindo! São fracos e estão enganando vocês! São de Satanás!". No começo, quando eu ainda era muito jovem, tinha medo da fala desses forasteiros e, por causa delas, cheguei a duvidar dos xapiri. Por algum tempo, me deixei enganar por essas más palavras e até tentei, com muito esforço, responder às palavras de Teosi. Mas isso acabou mesmo! Faz muito tempo que eu não deixo mais as mentiras dos brancos me confundirem e que não me pergunto mais: "Por que eu não tento virar um deles?". Tornei-me homem, meus filhos cresceram e tiveram seus próprios filhos. Agora, nunca mais quero ouvir más palavras sobre os xapiri! Omama os criou depois de ter desenhado nossa floresta e, desde então, eles continuaram cuidando de nós. Eles são muito valentes e muito bonitos. Seus cantos fazem nosso pensamento aumentar em todas as direções e ficar firmes. E por isso vamos continuar fazendo dançar suas imagens e defender suas casas, enquanto estivermos vivos. Somos habitantes da floresta. É o nosso modo de ser e são estas palavras que quero fazer os brancos entenderem. (KOPENAWA \& ALBERT, 2015, p. 511).

Novamente: a tradiçãoéretomada comooelemento distintivo e positivo da vida, da constituição e da autocompreensão do(a) intelectual indígena em seu posicionamento público-político, em seu ativismo e em sua militância em favor da causa indígena e sob a forma de crítica à modernidade/modernização. Aqui, como estamos enfatizando ao longo do texto, a tríade memória, autoafirmação e resistência-luta embasa e dinamiza uma vozpráxis de crítica do presente que parte exatamente da ênfase na comunidade de origem, em seus valores e em suas práticas, que rememora processos, sujeitos e práticas coloniais, excludentes e violentos e que, a partir disso, reforça a postura de resistência e de luta a todo custo - e como última alternativa - contra os processos de descaracterização, de negação e de destruição 
sofridos e vividos ainda hoje. Assim, visibilizar-se, visibilizar a constituição antropológica e étnica, denunciar e desvelar sujeitos, práticas e valores coloniais e enfrentar de modo direto os desafios colocados pelo atual estágio da modernização - e mesmo o conservadorismo redivivo nas instituições políticas e entre os partidos políticos, para não se falar de nossa cultura comum como brasileiros - equivale em afirmar-se, via vozpráxis estético-literária, a origem, a tradição e os processos de negação dela, gerando essa postura de ativismo e de militância que dinamiza e define essa mesma produção estético-literária indígena em seu sentido profundamente político-politizante, carnal, personalizado e vinculado. Como diz Eliane Potiguara de modo enfático:

Desde o passado até os dias atuais, o território e a cultura indígenas têm sido as linhas mestras de determinação para a sustentação de um povo. Quando dizemos território, não estamos simplificando o termo para algo simples e final. Estamos expandindo o termo para algo mais digno no que se refere aos direitos dos povos indígenas. Um território não é apenas um pedaço ou vastidão de terras. Um território traz marcas de séculos, de cultura, de tradições. É um espaço verdadeiramente ético, não é apenas um espaço físico, como muitos políticos querem impor. Território é quase sinônimo de ética e de dignidade. Território é vida, é biodiversidade, é um conjunto de elementos que compõem e legitimam a existência indígena. Território é cosmologia que passa, inclusive, pela ancestralidade. Dentro desses parâmetros, os povos indígenas têm exaltado e perpetuado suas culturas contra o sistema social e político. A exaltação é uma forma de resgate e de preservação de algo. É a valorização daquilo que não é valorizado como deveria ser. Exaltação é afirmação, na poesia e na vida. (POTIGUARA, 2004, p. 105).

Nesse sentido, a autoafirmação e a autoexpressão por meio 
da retomada, da valorização e da ênfase na tradição comunitária, ancestral e xamânica levam direta e pungentemente à crítica do presente, a uma crítica do presente que tem na defesa e na promoção da vida e do lugar étnicos o seu ponto fundante e dinamizador. Assim como Davi Kopenawa enfatiza, valoriza e utiliza o tempo todo suas bases, suas práticas e seus valores antropológico-ontológicos, socioculturais e epistemológicopolíticos como substrato para sua autocompreensão e para seu enquadramento dos processos de modernização, para denúncia da marginalização, da exclusão e da violência sofrida, Eliane Potiguara, Kaká Werá Jecupé, Ailton Krenak, Olívio Jekupé e Daniel Munduruku, no mesmo diapasão, partem do lugar e do contexto da fala, isto é, a condição indígena e sua situação de violência simbólico-material, para denunciar exatamente a continuidade dos processos de violação da terra, da cultura e da dignidade próprias aos povos indígenas. Aqui, é por meio de uma permanente rememoração e afirmação da tradição, da comunidade de origem, de sua riqueza, de sua singularidade, da importante contribuição que ela pode dar a uma noção mais ampla, inclusiva e diversificada de humanidade, pelo simples direito de continuar vivendo nessa sua singularidade, que a voz-práxis estético-literária torna-se militante e ativista, política e politizante, carnal, personalizada e vinculada, afinal, como estamos dizendo, narrar e falar sobre a própria condição antropológica, visibilizar e desvelar a situação de marginalização, de violência e de negação, tudo isso somente pode ser feito de modo direto, uma vez que uma minoria é irrepresentável e insubstituível enquanto sujeito da práxis, como práxis política. Reconhecer e assumir essa responsabilidade como minoria, de autoafirmar-se e, ao mesmo tempo e como 
condição disso, resistir e lutar, enfatizar a memória comunitária e narrar e denunciar publicamente a violência vivida e sofrida, e desde uma perspectiva poético-literária, esse é um mérito que os povos indígenas, em seus/suas intelectuais e sob a forma do movimento indígena, têm assumido e realizado efetivamente na esfera público-política e, com cada vez mais intensidade, na própria academia, o que transforma a voz-práxis estético-literária e seus produtos simbólicos diretamente em ativismo e militância políticos e politizantes, carnais, vinculados e personalizados.

\begin{abstract}
Nosso ancestral dizia: Temos vida longa!/Mas caio da vida e da morte/E range o armamento contra nós./Mas enquanto eu tiver o coração aceso/Não morre a indígena em $\mathrm{mim} / \mathrm{E}$ nem tampouco o compromisso que assumi/ Perante os mortos/De caminhar com minha gente passo a passo/E firme, em direção ao sol./Sou uma agulha que ferve no meio do palheiro/Carrego o peso da família espoliada/Desacreditada, humilhada/Sem forma, sem brilho, sem fama. (POTIGUARA, 2004, p. 102-103).
\end{abstract}

\title{
Considerações finais
}

Aqui chegados, gostaríamos de traçar e sustentar duas breves ideias que, em nossa perspectiva, servem como base para acessarmos o texto-práxis das minorias de um modo geral e, em particular, no caso deste artigo, o posicionamento intelectual e as produções estético-literárias indígenas. O primeiro deles consiste exatamente na postura de politização que caracteriza e que dinamiza a voz-práxis estético-literária das minorias e, por conseguinte, o sentido profundamente militante e ativista de suas produções, uma vez que a própria expressão pública das minorias representa um enquadramento e uma contraposição 
diretos e pungentes dos sujeitos, das práticas e dos valores unidimensionais e normalizadores, em uma perspectiva de crítica, de politização e de historicização de tudo aquilo que está naturalizado, ossificado e percebido e afirmado de modo a-histórico. A voz-práxis estético-literária das minorias é política porquea politização-politicidade ésua expressão-posicionamento ab origine, como minoria - inclusive e porque a minoria é uma construção política e sua emancipação é e envolve a politização, conforme enfatizamos ao longo do texto e, em especial, no primeiro capítulo. Além disso, o posicionamento público das minorias, em termos dessa sua voz-práxis militante e ativista, é radicalmente político por colocar em xeque o sentido a-histórico, essencialista e naturalizado dos valores, das práticas e dos sujeitos normalizados-normalizadores, impulsionando por sua atualização, reelaboração e, não raro, necessidade de superação, o que exige permanente politização de tudo o que é apolítico e despolitizado, de tudo o que é unidimensional, massificador e totalizante, situação incompatível com a possibilidade de as diferenças existirem em sua singularidade e em igualdade de condições. Ora, onde não há politização, não pode haver diferenças, mas exclusão, marginalização e violência; no mesmo diapasão, onde não há diversidade e pluralidade, também não pode haver politização inclusiva e participativa, posto que assume-se uma e vive-se numa sociedade unidimensional e, portanto, apolítica, naturalizada, a-histórica. O segundo deles, e umbilicalmente ligado ao primeiro, está em que a voz-práxis autoral das minorias é marcada pela imbricação e mútuo suporte entre eu e nós, de modo que, no caso das minorias, temos um eunós lírico-estético-político que interliga de modo indissociável e inextricável o(a) autor(a) com a comunidade ou o grupo de 
origem, o que torna essa mesma voz-práxis estético-literária das minorias e seus produtos artísticos carnais, vinculados, personalizados e, em tudo isso, politizados, como resistência e luta contra a exclusão, que acontecem por meio exatamente da ênfase na comunidade e no grupo como sujeito, contexto e valor ampliados da própria expressão, da própria luta.

Nesse sentido, nas produções estético-literárias das minorias por elas mesmas tem-se a voz-práxis como ativismo e militância, o texto como ativismo e militância políticos e politizantes, o que significa que ele não é autorreferencial, nem sua análise pode ser exclusivamente autorreferencial, técnica, cientificista (o texto pelo texto, por assim dizer). Aqui, a minoria (o eu-nós líricoestético-político) é ativista-militante, se compreende e se porta como tal e o resultado final de seu produto é exatamente essa práxis militante e ativista. Com isso, acreditamos que a expressão artístico-literária das minorias poderia ser enquadrada a partir do tipo de denúncia e da forma de aprendizado moral, político, epistêmico e estético que ela efetivamente fomenta e gera. Aqui está sua grande riqueza e seu enorme poder normativos, políticos formativos: a emancipação por meio da publicização da condição de marginalização, de violência e de exclusão - a reflexividade e a emancipação para todos, não só para as minorias, uma reflexividade e uma emancipação que dependem da pluralização e da publicização das vozes, das histórias, das práticas e dos valores. Em nosso caso, portanto, trata-se de ler, interpretar e perspectivar politicamente a condição de vítima, de minoria como o critério basilar para enquadrar-se a literatura de minorias e, nela, a literatura indígena. Esta, com efeito, se constitui a partir da tríade memória, autoafirmação e resistência-luta, o que nos permitiu definir, ao longo do texto, a voz-práxis estético- 
literária indígena como sendo perpassada e dinamizada pela retomada, pela ênfase e pela utilização da tradição comunitária, ancestral e xamânica como crítica do presente, como crítica à modernização, como politização e visibilização da condição e da questão indígenas na esfera pública e enquanto esfera pública. Aqui, a valorização e a utilização dessa tradição comunitária, ancestral e xamânica como núcleo constitutivo, definidor e dinamizador da voz-práxis indígena tem o poderoso efeito de politizar não apenas o posicionamento do movimento indígena desde sua especificidade antropológica, mas também a própria imposição de modelos de desenvolvimento e de modernização da floresta, da terra, da população em geral, algo que o mercado, as instituições públicas e os partidos políticos, no mais das vezes em concerto profundo, o fazem desde um prisma técnico, apolítico, neutro, impessoal e imparcial - a técnica como interrompendo e deslegitimando qualquer perspectiva normativa sobre essa mesma modernização, tornando seu enquadramento e sua legitimação um problema basicamente institucional, lógicotécnico, que passa a ser assumido e imposto de modo vertical, de cima para baixo. Com base na sua tradição comunitária, o indígena pode de modo aberto argumentar publicamente em torno ao sentido metafísico, normativo e político da terra, da natureza, do humano, inclusive apontar para a existência da diversidade paradigmática que constitui e que perpassa nossas interpretações sobre nosso lugar no mundo e frente aos outros e sobre o modo como podemos abordá-los, relacionarmo-nos com eles. Nesse caso, sem a consideração das diferenças e, em particular, das minorias, a política é substituída pela técnica, o diálogo pela tecnocracia e o(a) cidadão(a) pelo(a) especialista; sem a pluralização dos sujeitos, das perspectivas, das práticas 
e dos valores, saímos do mundo da política - que depende sempre do pluralismo, da contradição - e entramos no mundo da naturalização e da a-historicidade absolutas, um mundo marcado pela interrupção da política, pela não-política. Novamente: sem as minorias, sem as diferenças, não há política, reflexividade, aprendizado e emancipação. E isso mostra o profundo sentido político-pedagógico da literatura de minorias, da literatura indígena, por meio delas, a partir delas.

\section{Referências bibliográficas}

ALMEIDA, Maria Inês de. Desocidentada: experiência literária em terra indígena. Belo Horizonte: Editora UFMG, 2009.

ALMEIDA, Maria Inês de; QUEIROZ, Sônia. Na captura da voz - as edições da narrativa oral no Brasil. Belo Horizonte: Autêntica; FALE/UFMG, 2004.

ARFUCH, Leonor. O espaço biográfico: dilemas da subjetividade contemporânea. Tradução Paloma Vidal. Rio de Janeiro: EdUERJ, 2010.

BENJAMIN, Walter. Magia e técnica, arte e política: ensaios sobre literatura e história da cultura. São Paulo: Brasiliense, 1987.

BONVINI, Emilio. "Textos orais e texturas orais". In: Queiroz, S. A tradição oral. FALE/UFMG, p. 5-24, 2006.

CÉSAR, América Lúcia Silva. Lições de abril: a construção da autoria entre os Pataxó de Coroa Vermelha. Salvador: EDUFBA, 2011.

CESARINO, Pedro Niemayer. Oniska: poética do xamanismo 
na Amazônia. São Paulo: Perspectiva: FAPESP, 2011.

CLIFFORD, James. A experiência etnográfica: antropologia e literatura no século XX. 3 ed. Rio de Janeiro: Editora UFRJ, 2008.

COSTA, Suzane Lima. "Povos indígenas e suas narrativas autobiográficas". In: Estudos Linguísticos e Literários, n. 50, p. 65-82, jul-dez, Salvador, 2014.

DALCASTAGNÉ, Regina. Literatura brasileira contemporânea: um território contestado. Vinhedo: Editora Horizonte, 2012.

D’ANGELIS, Wilmar da Rocha. "Contra a ditadura da escola". In: Caderno Cedes, Campinas, Ano XIX, nº 49, p. 18-25, 1999. D’ANGELIS, Wilmar da Rocha. Como nasce e por onde se desenvolve uma tradição escrita em sociedades de tradição oral? Campinas, SP: Curt Nimuendajú, 2007.

FEIL, Roselene Berbigeier. "O (não) lugar do indígena na 'literatura brasileira': por onde começar a inclusão?’ In: Boitatá (Londrina), p. 122-137, 2011.

FERNANDES, Estevão Rafael. "Ensino de filosofia e cultura amazônica: Uma apologia aos saberes periféricos". In: DANNER, Leno Francisco. (Org.). Ensino de Filosofia e Interdisciplinaridade. Porto Alegre: Editora Fi, p. 124-148, 2013.

FERNANDES, Estevão Rafael. "Quando existir é resistir: Twospirit como crítica colonial”. In: OLIVEIRA, Marcus Vinicius Xavier de; DANNER, Leno Francisco; DANNER, Fernando; DORRICO, Julie (Orgs.). As diferenças no ensino de filosofia: reflexões sobre filosofia e/da educação. Porto Alegre, RS: Editora Fi, p. 291-396, 2017.

FINNEGAN, Ruth. "O significado da literatura em culturas orais”. In: QUEIROZ, S. (Org.) A tradição oral. FALE/UFMG, p. 64-102, 2006. 
GOLDEMBERG, Deborah; CUNHA, Rubelise da. "Literatura indígena contemporânea: o encontro das formas e dos conteúdos na poesia e prosa do I Sarau das Poéticas Indígenas”. In: Espaço Ameríndio. Porto Alegre, v. 4, nº 1, p. 117-148, 2010.

GRAÚNA, Graça. Contrapontos da literatura indígena contemporânea no Brasil. Belo Horizonte: Mazza Edições, 2013.

GRAÚNA, Graça. "Identidade indígena: uma leitura das diferenças". In: POTIGUARA, Eliane. Metade cara, metade máscara. São Paulo: Global Editora, 2004, p. 17-21, 2004.

GUEDES, Peonia Viana. "Narrando o sujeito feminino de origem indígena: práticas autobiográficas na construção de identidades pessoais e culturais”. In: HARRIS, Leila Assumpção (Org.). A voz e o olhar do outro. Rio de Janeiro: Letra Capital, p. 68-80, 2009.

JECUPÉ, Kaká Werá. Oré Awé Roiru'a Má: todas as vezes que dissemos adeus. São Paulo: TRIOM, 2002.

JEKUPÉ, Olívio. Xerekó Arandu: a morte de Ângelo Kretã. São Paulo: Peirópolis, 2002.

KLINGER, Diana Irene. Escritas de si, escritas do outro: autoficção e etnografia na narrativa latino-americana contemporânea. Tese de doutorado, Programa de PósGraduação de Letras da UERJ, Rio de Janeiro, 2006.

KOPENAWA, Davi; ALBERT, Bruce. Aqueda do céu: palavras de um xamã yanomami. $1^{a}$ edição. São Paulo: Companhia das Letras, 2015.

KRENAK, Ailton. Encontros. Organização de Sérgio Cohn e de Idjahure Kadiwel. Rio de Janeiro: Azougue Editorial, 2015.

LIBRANDI-ROCHA, Marília. "Escutar a escrita: por uma teoria literária ameríndia". In: O eixo e a roda, Belo Horizonte, v. 21, n. 2, p. 179-202, 2012. 
MIGNOLO, Walter. La idea de América Latina: la herida colonial y la opción decolonial. Barcelona: Editorial Gedisa, 2007.

MUNDURUKU, Daniel. Memórias de índio: uma quase autobiografia. Porto Alegre: Edelbra, 2016.

MUNDUKU, Daniel. "Visões de ontem, hoje e amanhã: é hora de ler as palavras". In: POTIGUARA, Eliane. Metade cara, metade máscara. São Paulo: Global Editora, 2004, p. 15-16.

POTIGUARA, Eliane. Metade cara, metade máscara. Editora Global, São Paulo, 2004.

RANCIÈRE, Jacques. O ódio à democracia. São Paulo: Boitempo, 2014.

RANCIÈRE, Jacques. A partilha do sensível: estética e política. São Paulo: Editora 34, 2009.

RISÉRIO, Antônio. Textos e Tribos - poéticas extraocidentais nos trópicos brasileiros. Rio de Janeiro: Imago Editora, 1993.

SÁ, Lúcia. Literatura da floresta: textos amazônicos e cultura latino-americana. Rio de Janeiro: EdUERJ, 2012.

SÁEZ, Oscar Calavia. "Autobiografia e liderança indígena no Brasil". In: Tellus, Campo Grande - MS, ano 7, n. 12, p. 11-32, 2007.

SÁEZ, Oscar Calavia. "Autobiografia e sujeito histórico indígena”. In: Novos Estudos (CEBRAP), São Paulo, n. 76, p. 179-195, 2006.

THIÉL, Janice Cristina. Pele silenciosa, pele sonora: a construção da identidade indígena brasileira e norteamericana na literatura. Tese de doutorado, Programa de Pós-Graduação em Letras da Universidade Federal do Paraná, Curitiba, Paraná, 2006. 


\section{Sites consultados:}

Bibliografia das publicações indígenas do Brasil. Organização de Aline Franca, Daniel Munduruku e Thulio Dias Gomes. Data de acesso: 04/04/2019. Disponível em:

https://pt.wikibooks.org/wiki/Bibliografia_das publica $\% \mathrm{C} 3 \% \mathrm{~A} 7 \% \mathrm{C} 3 \% \mathrm{~B} 5 \mathrm{es}$ ind $\% \mathrm{C} 3 \% \mathrm{ADgenas}$ do Brasil/ Lista_de_autores_(por_origem) 